\title{
SLOWMATION AS A PEDAGOGICAL SCAFFOLD FOR IMPROVING SCIENCE TEACHING AND LEARNING
}

\author{
Stephen Keast, Centre for Science, Maths and Technology Education, Monash University, Australia, \\ $<$ Keasty@monash.edu> \\ Rebecca Cooper, Centre for Science, Maths and Technology Education, Monash University, \\ Australia, <Rebecca.Cooper@monash.edu> \\ Amanda Berry, Centre for Science, Maths and Technology Education, Monash University, Australia, \\ <Amanda.Berry@monash.edu > \\ John Loughran, Centre for Science, Maths and Technology Education, Monash University, \\ Australia, < John.Loughran@monash.edu> \\ Garry Hoban, Faculty of Education, University of Wollongong, Australia, <ghoban@uow.edu.au>
}

\begin{abstract}
In this study, two classes of General Science Teaching Method preservice secondary teachers at Monash University $(\mathrm{n}=38$ in 2007 and $n=34$ in 2008) developed Slowmation movies as part of their course work, then introduced Slowmation into the their science classrooms during their school practicum. On returning to university following their practicum these preservice teachers shared the Slowmations created by their students during the practicum, and discussed the impact of introducing this procedure on their students' learning about science concepts. The classroom presentations and discussions of school students' Slowmation movies post practicum provided valuable feedback to the preservice teachers about their teaching and their students' learning. The data illustrated that these preservice teachers became aware of a range of conceptions held by their learners about particular science concepts through their students' Slowmation movies and in so doing, influenced their understanding of science teaching and learning.
\end{abstract}

\section{Introduction}

Slowmation is a Teaching Procedure based on elements of clay animation designed to engage students in constructing ways of demonstrating concepts and ideas. In contrast to clay animation where clay or plasticine figures are photographed and shown quickly to simulate continuous 'near life' movement, Slowmation uses a variety of materials and is played at 2 frames per second to produce "slow animations" (hence the term Slowmation). In this study, the Slowmation process was introduced to preservice secondary science teachers who made short movies about abstract science concepts. The purpose of using Slowmations in this way with preservice science teachers was in order to explore their understanding of science concepts. In so doing, it was anticipated that they might see the value in using the procedure with their students when they were teaching (on their practicum) and therefore gather insights into their students' understanding of science concepts.

Slowmation has been pioneered by Hoban (Hoban, 2007; Hoban \& Ferry, 2006; Hoban, McDonald, \& Ferry, 2009) at the University of Wollongong through extensive work with Primary preservice teachers over several years with a major goal of producing useful classroom resources in science. The Slowmation process has proven to be remarkably successful in engaging pre-service teachers with some participants spending upwards of 20 hours outside of scheduled class time to produce movies to be shared through an online forum. Hoban's work led to a successful Australian Research Council (ARC) Discovery Project (Hoban, et al., 2008) spanning three universities 
(Wollongong University, Monash University and University of British Columbia) and two continents (Australia and Canada).

At each site, the particular focus of the ensuing research varies. At Monash University, Slowmation is being used by preservice secondary teachers (Double Degree $4^{\text {th }}$ year and Graduate Diploma of Education) as part of their General Science Curriculum unit. The General Science Curriculum unit is designed to prepare preservice teachers to teach general science Years 7 to 10 in secondary schools and most of these preservice teachers also generally have a specialist science method e.g., Biology, Chemistry or Physics. Through the Monash component of the program, Slowmation is being used as a way of encouraging preservice teachers to begin to identify their students' alternative conceptions in science.

This paper offers an initial investigation of the work being conducted at Monash University into how Slowmation can be used by preservice secondary teachers to identify their students' alternative conceptions, and explores preservice teachers' views of Slowmation as a Teaching Procedure.

\section{Research Approach}

An integral part of the General Science Curriculum unit is to encourage preservice teachers to better understand what it means to teach science from a constructivist perspective. Such a perspective is based on the view that "learners interpret and interact with the physical world through their conceptualizations of phenomena" (Scott, Asoko, Driver, \& Emberton, 1994, p. 201). As constructivist studies have demonstrated for some time, learners bring their own prior views of science to the classroom based on the ways in which they conceive of particular concepts and ideas (Driver, 1994). Teaching informed by a constructivist perspective relies on the teacher acknowledging and identifying learners' alternative conceptions and creating experiences and opportunities for them to experience conceptual change. The expectation being that students might then develop deeper understandings of concepts as they move from their informal prior views toward the "accepted school view" of science (Fensham, Gunstone, \& White, 1994).

At Monash University, Slowmation is initially introduced to preservice teachers in the General Science Curriculum unit in a 2-hour tutorial. Through this session, preservice teachers have demonstrated to them the technicalities of producing a Slowmation, then in small groups produce their own Slowmation that they share with the rest of the class. This is facilitated by the lecturers (first two authors) modelling the teaching of Slowmation in such a way that the preservice teachers might adopt a similar approach with their own students when they are on their practicum. In so doing, they also inevitably face a typical dilemma faced by teacher educators. That is, there is a need to help their preservice teachers see beyond Slowmation as a 'fun activity' and to consider its pedagogical purpose in terms of its value as a thoughtful and carefully directed Teaching Procedure - this is not as simple as it sounds because coming to master the skills of Slowmation can inadvertently mask the pedagogical value as the doing can become the main focus and the underlying thinking and learning can remain somewhat tacit in nature.

In teaching Slowmation as a teaching procedure, the teacher educators grapple with the purposes of their own teaching. Discerning the differences between conceptual knowledge, procedural knowledge, organisational knowledge and content knowledge is not always easy for preservice teachers and Slowmation also highlights the overlap between each which gives rise to different ways through which preservice teachers view the purpose of using Slowmation in their own classrooms. Initially the task is procedural, but (as this paper will demonstrate) on returning to university after teaching Slowmation the discussion of the task highlights the conceptual and therefore focuses attention on aspects of that which we would term pedagogical intent.

Mitchell (2007) clearly articulates the distinction between activities, teaching procedures and strategies. Activities he defines as "content and year level specific descriptions" (p. 3) of teaching events. When teachers meet to discuss their practice, they often talk in terms of activities. Although discussion around activities is important, it can also be limiting since it is content and year level specific. Teaching procedures, on the other hand, which Mitchell (2007) describes as the "generic (i.e., not subject-specific) features of the teaching ideas" (p. 2), encourages discussion of generic teaching ideas that can then be developed to suit a teacher's context, content and year level. By trialling and adapting teaching procedures (compared with sharing activities), teachers can build a 
sense of ownership in their teaching while adopting the ideas of others. By sharing knowledge of practice in this way it is suggested that the development of a common language about teaching and learning can be encouraged. Teaching procedures have been fundamental to the Project for Enhancing Effective Learning (PEEL, Baird \& Mitchell, 1986; Baird \& Northfield, 1992) in building and sharing teachers' professional knowledge. The development of such professional knowledge has led to the creation of several constructs that PEEL teachers now use in discussing their teaching, i.e., Poor Learning Tendencies and Good Learning Behaviours (Mitchell \& Mitchell, 1997).

As a Teaching procedure, the emphasis on Slowmation in the Monash component of this project is focused on the teaching and learning issues that are raised in relation to students' learning of science concepts. When introducing Slowmation to preservice teachers, the first two authors emphasise a number of key ideas that are integral to the learning processes involved in the use of Slowmation:

1. Representation: recognising a whole process

2. Deconstruction: analysing the component elements

3. Reconstruction: synthesising the whole process

In conceptualising Slowmation as a three step process (representation, deconstruction and reconstruction), preservice teachers are encouraged firstly, to examine the nature of the science concept under consideration. They consider how the concept might best be represented as a process (reflect on their understanding of the concept). They then deconstruct the science concept into that which they see as the major elements of the process (i.e., chunking) through the use of a storyboard, and then reconstruct it through the model making and movie (re-chunking and synthesizing). As part of the reconstruction process, playing the movie to the class and explaining it (commentary/narration) is an important aspect of the learning that helps to convey the authors' thinking and understanding about the concept - both to themselves and their audience. For example, one preservice teacher came to recognise that while they represented in one way, DNA is more than just a helix, "they are more like, 'squished' together. It had never occurred to me to consider how they were positioned within the cell until a girl asked me in class." (PST5, Classroom presentation, 2007)

In this way, Slowmation as a teaching procedure may be categorised as a Translation Task (Mitchell, 2007) in which learners translate information from one form into another. In this case, Slowmation requires students to translate abstract scientific information into models to produce animated movies that demonstrate their understanding of the given concept, topic, or idea under consideration. Slowmation used in this way has been a pedagogical tool allowing the preservice teachers to explore their developing ideas of pedagogy as they develop deeper understandings of teaching.

The first two authors believe that a central aspect of our pedagogy of teacher education (Loughran, 2006) is to assist preservice teachers to articulate their developing understanding of pedagogy so that they begin to conceptualize practice as much more than the delivery of information or the introduction of 'fun activities'. Ostensibly, we are working in ways that are designed to help our preservice teachers begin to see, feel and experience teaching as problematic.

\begin{abstract}
Aims
The aims of this study were to evaluate preservice teachers' perceptions use of slowmation for teaching and learning in secondary science classrooms whilst on their teaching practicum. More specifically, we wanted to consider what the preservice teachers found out about teaching and learning science for using slowmation with secondary school students.
\end{abstract}

\title{
Methodology
}

\section{Research Design}

The research design in this study draws on the work of Nicaise and Crane (1999) who conducted similar research on the knowledge construction of teachers enrolled in higher degrees at university when using hypermedia authoring tools. Like Nicaise and Crane, this Slowmation research design 
used a qualitative and descriptive approach drawing together data from multiple sources: preservice teachers' presentations of their students' Slowmation movies; lecturers' field notes from presentation sessions; journals kept by the lecturers (first two authors); and, the lecturers' guided reflections on each other's journals.

\section{Classroom Context}

Such a research design then led to a grounded theory framework for analysis such that knowledge was built-up from the complex description of the classroom (Nicaise \& Crane, 1999) and lecturer-student, student-lecturer, lecturer-lecturer and student-student interactions. The preservice teacher participants involved in this study spent five weeks in schools on their teaching practicum. For those with a Science specialism, they are expected to teach at least one class of General Science (Years 7-10) for the duration of their practicum (approximately 4 lessons per week over 5 weeks), in addition to their other specialism. The Science Education course is for preservice secondary science teachers in their 4th year of a Bachelor of Education (as part of a double degree with a Bachelor of Science) or may be completing a Diploma of Education one year course. This unit is a semester long course that runs in second semester and is prepared and taught by the first two authors using a team teaching approach. During the course the preservice teachers are introduced to models of pedagogical knowledge with the intention of using this as a developmental tool to frame and reflect on their practice, shown video of quality science teaching practice for them to analyse, challenged with the idea of teaching sex education and ethical issues in science and introduced to the use of slowmation as a way of illuminating students' alternate conceptions. The preservice teachers have already completed one teaching placement prior to this unit and they complete a second teaching placement during the middle weeks of the course. As part of their General Science Curriculum unit the preservice teachers are asked to teach Slowmation to their students during practicum and to show their students' completed movies to their General Science peers on their return to the university.

\section{Sample}

The sample of the study consisted of Seventy two (38 in 2007 \& 34 in 2008) preservice teachers. The preservice teachers in the unit are $75 \%$ females to $25 \%$ males and come from a diverse range of backgrounds. Some have entered the Education degree as their first university course directly from secondary school (BEd./BSc.). Other students (Dip.Ed.) have completed at least an undergraduate degree in science and usually have worked for some years as in scientific community. There are about $10 \%$ of the students in this unit that have a $\mathrm{PhD}$ in a field of science, have worked in science research and are making a career change.

\section{Data Collection Procedure}

The first two authors collected data from preservice teachers' experiences of doing this in the form of tape recording the presentations in the General Science class on their return to university following the practicum (Setiawan 2020a; 2020b). In addition, following each lesson, the first two authors also met regularly to discuss their teaching (guided reflection) which offered more formalized individual data sets through reflections in their journals. The General Science Curriculum unit from which journal data and field notes were drawn comprised of all the 72 preservice teachers. The tape recordings of the presentations were transcribed and along with the field notes and journals maintained by the first two authors, as well as the Slowmations the preservice teachers presented were analysed to offer an initial investigation of these preservice teachers' understanding of the use of Slowmation in their teaching of secondary school science. All quotations used are drawn from these data sets outlined above and are offered as indicative quotes of given situations.

Upon return to University from their practicum, preservice teachers had to present the Slowmations that their students had made and talk about their experiences of and the process of teaching using Slowmation (Setaiwan \& Mufassaroh, 2019). Slowmation became a shared experience for the preservice teachers around which their discussions of teaching were based. These discussions become a way to unpack the pedagogical value of Slowmation as they moved beyond the idea of Slowmation as a 'fun activity'. During these discussions, the teacher educators tried to be 'invisible' so that the preservice teacher who was presenting would lead and chair the discussion. We felt that this was important to ensure that the preservice teachers did not feel that there was one 'right way' to 
use Slowmation. During these discussions many issues of teaching and learning were raised that allowed the preservice teachers to explore their developing notions of pedagogy with their peers. Surprising to the authors they began to verbalise their pedagogy and were made to justify their use of various strategies, the timing of Slowmation in the unit, the way they created groups and what they did and did not assess. The discussions were recorded and analysed to identify the main issues of teaching and learning that the preservice teachers identified when using Slowmation on their teaching rounds and these main ideas are expanded upon in the following.

\section{Results}

The results of the study are reported under two headings: (i) Slowmation as a Teaching Procedure and (ii) Understanding Learning:

\section{Slowmation as a Teaching Procedure}

Under this heading the authors examine the learning of the preservice teachers as they discuss their experiences of using Slowmation as a teaching procedure in their own classrooms while on practicum.

Learning about how to teach Slowmation. In terms of structural outcomes (i.e., lesson organisation, planning and instruction), participants suggested that introducing Slowmation required several lessons; it worked best when developed over about four 50 minute periods; with a double period used to take the photographs. The first lesson entailed setting the scene, showing some examples, allocating topics and beginning the storyboards. Students completed the storyboards between lessons one and two. The second and third lessons were generally used for making the models and taking the photographs. Between lessons two and three (if not a double lesson), and lessons three and four, students edited their movies and presented them back to the class in lesson four.

As is the case in secondary schools, the specific time period allocated to subjects imposes certain constraints. Participants found as a consequence of these time restrictions, that the scientific concept to be studied needed to be manageable or self contained; such as DNA replication or how electricity flows in wires. Concepts that had multiple parts or were overly complex led to the makers oversimplifying the concepts so that the alternative conceptions were not distinguishable from conceptual errors. Student teachers described their responses to these situations in similar ways, for example:

On reflection I wouldn't do such a big content area for the students' Slowmation movies ... I would reduce the amount of content that had to go into their movies if I had to do it again. (PST1, Classroom presentation, 2007)

I had Year 9 Forensics and Year 11 Biology, and for the life of me, my supervisor and I, couldn't think of anything to do with forensics that was suited to Slowmation. So I did it for animal behaviour in Year 11. Which didn't particularly suit the Slowmation either but it worked out ok. ... [later in the discussion] Yeah, it's like what could the tiny specific topics be that you could tell the kids would be appropriate [in forensics]. (PST2, Classroom presentation, 2007)

An additional benefit that preservice teachers found in using this approach was that by covering several related scientific concepts relevant to a topic, movie presentations then worked well as a revision session for students. In this way, the preservice teachers started to articulate their developing notions of pedagogy through their shared discussions of using Slowmation with students in classrooms. As part of this notion of a manageable self contained concept in science, preservice teachers also began to recognize that some concepts were not quite as simple and straightforward as they had initially imagined. Working with science concepts at a technical level (in terms of Slowmation as a teaching procedure) introduced preservice teachers to new understandings of the complexity of some abstract science concepts.

In all the movies we looked at the students showed DNA just as a helix, but we know that in the cell, the DNA doesn't exist as just a helix. They are more like, 'squished' together, none of the ones we have looked at have shown this. And in my class when students made models of DNA 
they made just the helix and I don't think they ever thought how it was connected within the cell. (PST8, responding to a movie, Classroom presentation, 2008)

I also had students ask me how do you get such a long thing (DNA helix) inside a tiny cell. (PST3, Classroom presentation, 2008)

These preservice teachers developed clearer ideas of the demands of the content through their discussions of their students' Slowmation movies.

\section{Understanding Learning}

In this section the authors discuss five aspects of the preservice teachers learning that came from using Slowmation in their own teaching: Learning about students' alternative conceptions, Learning through Slowmation, Meta-learning, Learning about teaching and Finding freedom to act.

Learning about students' alternative conceptions. The preservice teachers agreed that the process of Slowmation was useful for helping them to identify students' alternative conceptions of a science concept. One preservice teacher commented:

The major conception they had before they started, was they had the light and dark reactions mixed up [in photosynthesis], and didn't show how the process worked, but this was picked up in the storyboard process and I was able to help with that. I didn't have time to follow this up as it was the second last day [of the practicum], so I cannot tell if that is what they really meant or [if] it is just how they represented it. But the Slowmation did reveal to me areas that students didn't fully understand and where I needed to re-teach the ideas. (PST1, Classroom presentation, 2007)

You might have noticed in that one (the nervous system and reflex reactions) there was no interneuron, and when you get something transferred by a sensory neuron it goes to an inter-neuron first and then onto a motor neuron. And that is the general sequence. There was no inter-neuron shown in that [the Slowmation] and there wasn't any mention of it in their written explanation either. (PST3, classroom presentation, 2008)

Through observing their students developing their Slowmations, preservice teachers came to see opportunities in which they could investigate their students' knowledge and therefore begin to identify their alternative conceptions. They found a variety of ways to feed back this information to their students which included:

- writing on sticky notes and sticking these to students' storyboards;

- writing on the storyboard itself; commenting on 'rehearsals' of the Slowmation;

- offering feedback on the script for the narration; or,

- talking to the students whilst watching the final product and offering suggestions about possible changes.

From their experiences, these preservice teachers were able to identify common areas of alternative conceptions amongst their students and began to consider how to improve their explanation of this area of content in relation to their subsequent teaching. In terms of learning about teaching, preservice teachers began to realise that telling the class once does not address their students' alternative conceptions. That conceptual change is a difficult aspect of learning and this has major implications for their teaching. Such nuances of teaching assisted the preservice teachers to develop their understanding of the pedagogy.

(PST3 continues from above.) I think the reason for that was, because they were basing their thinking [understanding] solely on a diagram they got out of the text book that was very, very, simplistic and they didn't really do much of the reading. And I didn't realise that until after I had seen the movie. ... and I thought maybe I should have included that [in my teaching]. (PST3, classroom presentation, 2008) 
In this movie, they have taken survival of the fittest to mean the survival of the biggest and the strongest at the top of the food chain. Rather than the process of survival as in evolution. (PST9) Yeah so they have mixed up survival of the fittest with the food chain. A bigger animal or scarier animal kills a smaller animal and survives. (PST10, classroom presentation, 2008)

One valuable aspect of the Slowmation process for the preservice teachers was that it helped them to become more aware of (sometimes) small aspects of individual understanding that needed clarification, for example such things as the definition of one word that links other parts of a sequence; one preservice teacher commented:

One of the really good things I found out from them doing it [Slowmation] was, when you saw those little green snake things coming in, I hadn't realised, but the students thought that was the sugar-phosphate backbone of the DNA, and they thought it just miraculously appeared and climbed in there, and joined with the rest of the structure. They didn't realise that it was actually already connected to the bases. So that was a really good thing that I learned from them not understanding, that I only would have picked up from Slowmation. So I realised if I taught that again I would have to be really clear on that bit, because obviously they didn't understand it from the way I had explained it. (PST4, Classroom presentation 2007)

(PST5 2008 commented about another preservice teacher's students' movie). When I taught Mitosis on my previous round I noticed they thought it was a process that went phase 1, phase 2, phase 3, etc. not that it gradually changed. They just think they [cells] divide and that's it, not that it's a cyclic process. [PST6 2008 responds to that with:] That's what we got at the end of our video, in fact we didn't even get two cells. We actually got, they've pulled apart, that's it. That's the end of the process. I think that's one of the things I would address, like with animation, and could show, the connection of the processes rather than just stage 1, stage 2, stage 3. (PST6 Classroom presentation 2008)

Here are further examples of preservice teachers were discussing their own notions of pedagogy. Through tentative, hypothetical and exploratory talk instigated by the Slowmation movies the preservice teachers engaged in the issues of pedagogy from a common experience.

Learning through Slowmation: Slowmation leant itself to group work and allowed several students to work together to meet a common goal. Preservice teachers learnt about how different classes worked differently using the same task:

And for Year 9 ... their groups didn't work well, but for Year 10 the groups did work well together ... (PST1, Classroom presentation 2007)

Through the Slowmation task, another preservice teacher learnt about her preferred approach to group work in her classroom. Planning for Slowmation and organising groups was a powerful learning experience for her.

I grouped them, there were different ability levels and different personalities, so I grouped them and that really paid off. It got students to work together who didn't normally work together. (PST 3, Classroom presentation 2007)

For this preservice teacher arranging the groups herself, considering the students who would work together and those who would not was important for how she came to understand more about student learning through the Slowmation task.

Realising that the effort they put into their teaching was rewarded by improved student learning, preservice teachers were encouraged to do extra planning for their teaching so that their lessons went well. However, they also became aware that group work can be problematic as students being busy and actually learning science are not necessarily the same thing:

In terms of group work, I found that everyone could be working hard, but not doing very much about science. So in groups of 3, I found one person tended to be the director, someone would be the media player whiz, who was getting it all going on the computer and someone would be really involved in making the models. But they wouldn't really engage with the science at all. So 
you couldn't say that they weren't working because they were, but they weren't doing the sort of work that I wanted. So I don't know what the answer to that would be, because to get everyone to do an individual one [Slowmation] is too time consuming and resource consuming. (PST2, Classroom presentation 2007)

PST2 (above) grapples here with the nature of the learning that was taking place within the groups. The emphasis from her university classes was that Slowmation should not just be a fun activity, but be understood as a teaching procedure that could be employed in ways to genuinely benefit the science learning of her students. However, what she noticed was that although her students were all working consistently on the task, they were not necessarily engaging with the science concept in the way she had anticipated. Interestingly though, it also appears as though she was still concerned with how to manage the teaching procedure ("to get everyone to do an individual one is too time consuming ...") more so than the learning of the science concept per se. However, during her presentation of her students' movies back at university after the practicum, when she raised this issue with her peers, good discussion ensued about whether or not the issue could be 'solved'. As a consequence, the preservice teachers involved in that discussion started to see teaching as messy and complex and that their teaching dilemmas did not necessarily have simple answers; rather they came to see a need to find strategies that worked for them in their context, i.e., they began to see teaching as problematic. Importantly, as these preservice teachers began to see teaching as being problematic, they also started to recognize that although they were familiar with Slowmation as a teaching procedure, that it was not something that was then simply applied in the same way all of the time. They had to be responsive to their context and be more sensitive to the ways in which their students interacted in their learning. Discussions of the problematic nature of teaching helped preservice teachers to further explore the pedagogy of secondary science teaching.

They really got into the peer reviewing [of chunking sheets], and this was the day my supervisor from university came to observe my class. And I was getting really upset that they were so noisy because usually I had really good feeling in the classroom. And I was getting upset that they were all talking. Then at the end the supervisor said they were all talking about the movies and [were] engaged. (PST4, classroom presentation 2008)

Keeping kids on task that is a big thing. And absenteeism, because one group had only 2 kids at the planning stage, 3 kids at the making stage, one kid did the written up piece. I think it changed the dynamics of the groups. (PST3, classroom presentation 2008)

Through their experiences of learning about and then using Slowmation, these preservice teachers also became more knowledgeable about how, when and why to use this teaching procedure in their science classes. They started to unpack their practice and began thinking carefully about Slowmation and how it could benefit their students' learning. They felt that there were concepts for which Slowmation was more suitable and concepts for which it was not so applicable.

I probably wouldn't do it with the one I did like Energy, Heat, Light and Sound one, [content areas are too board] ... When we saw the one in class [university class] the Mitosis/Meiosis ones I thought they were really powerful in picking up things [alternative conceptions], or DNA replication those were very powerful for me anyway so yeah those sorts of types I things [self contained topics]. (PST7, Classroom presentation, 2008)

Preservice teachers also came to recognise the pedagogical value of storyboarding - since it requires the maker to deconstruct the scientific concept and think about how the different elements 'work together'. However, in their classes it rapidly emerged that when these preservice teachers were teaching, that their students did not see the storyboards as important - not surprisingly they wanted to get straight on with making the models and taking photos. Persevering with storyboarding was recognized as helpful in identifying students' alternative conceptions and offered an opportunity to discuss the science with their students:

The students didn't want to do the storyboard but they learnt a lot from it and I could see their understanding. (PST1, Classroom presentation 2007) 
I checked their storyboards, and made sure they had science and commented, you know, have you got arrows to show where the forces are acting? (PST3, Classroom presentation 2007)

I gave them feedback as sticky-notes that they could pull off and redo their storyboard in those places. (PST1, Classroom presentation 2007)

So during the first class when we were doing the whole planning and everything, using the storyboards, I realised that a lot of the students really had no idea what geotropism, phototropism and that sort of thing actually meant. This was really surprising because it had actually been covered with their regular teacher. So I had to spend most of the class teaching how this worked and referring them to the text book. (PST 10, Classroom presentation 2008)

Like you said [other preservice teacher] they seemed to understand it when they did the stroyboarding and explained it to me, but then they put that to the side and went on to the next activity which was they thought was supposed to be fun. Hence their movie didn't reflect the understanding in the storyboard. (PST11, Classroom observation 2008)

Meta learning. Preservice teachers realised the importance of having their students talk about their movies as they played them to the class. By having their students explain their movies, the preservice teachers were able to clarify aspects that were unclear and probe their students' understanding:

... they had to go out the front and explain it, what was happening, when the movie showed each frame, otherwise it was quite unclear what was happening in some of them. (PST3, Classroom presentation 2007)

This way of accessing students' thinking about the science ideas was revealing to these preservice teachers in ways they had not previously recognized:

They didn't realise that bases were already connected as strands [in DNA replication]. So that was a really good thing that I learned from them about them not understanding that I only would have picked up from Slowmation. (PST4, Classroom presentation 2007)

So we turned one of the seeds upside down, so in one the root and the shoot were coming out of the top, and on the other the root and the shoot were coming out of the bottom. So they really had to think about what was happening, and what gravity has to do with it. (PST10, classroom presentation 2008)

Not only did presenting the movies for their peers reveal what students did not understand and the alternative conceptions they held, it also served as a most worthwhile review for preservice teachers of their own teaching. This was evident for example when PST4 reflected on her teaching of DNA replication in front of her peers (post practicum at the university):

So I realised if I taught that again I would have to be really clear on that bit, because obviously they didn't understand it from the way I had explained it. (PST4, Classroom presentation 2007)

Learning about teaching. Slowmation became a process through which these preservice teachers could highlight other skills aside from their students' apparent content acquisition. They commented that some students were able to get involved and use skills that then gave them new ways of engaging with the content:

Here is my student who didn't really like biology, was slow to grasp the concepts etc., but in Slowmation he was king of the class, he knew how to do everything. I think that was a real good thing for him, he was achieving in biology for the first time. (PST2, Classroom presentation 2007)

One preservice teacher used her practicum Slowmation tasks as part of her students' assessment for the unit she had taught. The issue of assessing group work later generated heated discussion at university, as the preservice teacher defended her rationale:

I did assess them. I used it as an assessable task, I assessed them on their contribution to research, their contribution to model making, their contribution to IT, quality of what they 
produced; not whether their models were any good, but whether their end movie conveyed the science correctly. (PST1, Classroom presentation 2007)

I gave them a peer and self assessment sheet, based on their own self assessment. If all members of the group said they wanted the same mark then I gave them the same mark. Some other groups said they didn't think they had worked well together and they deserved individual marks. In this case I would give them individual marks based on how I thought they contributed to the group and what they reported on their self assessment sheet. (PST2, Classroom presentation 2007)

This preservice teacher wanted her students to realise that she valued all of the components of the process, an important step in her learning about teaching given that at least initially, preservice teachers tend to focus on the 'end product' more than the process of learning. By sharing her ideas with her preservice teacher colleagues she raised issues about assessment to monitor the learning of her students and their understanding of scientific phenomenon. In this way she was clarifying for herself her own pedagogical understanding.

Finding freedom to act. A few preservice teachers found it difficult to initiate lessons in Slowmation during their practicum. Some of their school supervising teachers were reluctant to allow their preservice teachers to try Slowmation because they did not see that it would fit in with their term/unit plan. These supervisors viewed Slowmation as taking too much time away from teaching and felt that it did not achieve their particular needs. Other supervising teachers recognised Slowmation as a great activity but could not see the benefits of it for student learning or improving teachers' knowledge of their practice. (This clearly raises important issues in teaching about teaching and the implications of pedagogy in relation to Mitchell's explication of activities, teaching procedures and strategies noted earlier in the paper). One preservice teacher had the following experience:

I wasn't allowed to do Slowmation initially, my supervising teacher said it wasn't good and I wasn't allowed to do it, because they have all their lessons planned out for the semester. But then by the last week, she said, 'ok you can do your Slowmation thing now'. (PST3, Classroom presentation 2007)

The supervisor thought it [Slowmation] was great (PST10). Did he see it as a nice activity or as way to get look at what the students had been learning? (Author 1) I think he saw it as a nice activity really. Thought because we were using it as an assessment task he saw it as that way as well (a monitoring of learning tool) but he also saw that it took a lot of time and so maybe it wasn't as good for senior classes where there is a lot of content to cover. (PST10, Classroom presentation, 2008)

The girls that I was working with [all girls school] were pretty motivated themselves to do it. But again they were very passive [learners], so anything that got them to draw out what a particular process is, was just a good way to get something out of them, because usually when you ask them a question, just nothing. I found that part to helpful [for their learning]. (PST11, Classroom presentation 2008)

I wanted to allocate most of my teaching time to actually improve their learning process. A lot of them had never passed a science test before, so they were really disillusioned with science and at the end we did a test and everyone passed. And they were just like, "Oh my god! I have passed a science test, I can't wait to go home and tell mum". And it was a really good feeling (for me). Because I kept referring back to it [Slowmation] they could see the value in doing it. It wasn't like we just did it as fun activity and pushed it aside. But because we actually saw the learning that was taking place they really seemed to benefit from that as well. (PST12 classroom presentation 2008)

Other school supervisors felt that Slowmation took too much time and relied on too many resources. For these supervisors, there was a feeling that unless there was enough equipment to run this in very small groups it would not be workable or beneficial. 
The topic being taught was also seen as an issue as some school supervisors felt that Slowmation could not be used during certain topics (Setiawan, 2017). Though all preservice teachers managed to use Slowmation on their teaching rounds, for some it required considerable negotiation with their supervising teachers but overall, as the data suggests, these preservice teachers learnt new and interesting things about teaching by experimenting with this teaching procedure in their science classes during their practicum.

\section{Conclusions}

The pre-service teachers in this study came to see a variety of ways in which Slowmation could be used in the classroom and how it could assist in the development not only of their practice but also their students' learning. The preservice teachers in this study found that Slowmation worked best when they had a series of lessons in which to complete the task and when the lessons were structured in a particular way (first lesson for storyboarding, second and third for taking photos and the final lesson for presentations). Additional time was required for working on Slowmations as homework (completing storyboards and editing the movies). As the data illustrates, these preservice teachers' experiences suggest that Slowmations were most effective when the concept chosen was small, self contained and easy to chunk and represent.

Slowmation worked well as revision for a topic; taking the major concepts of the topic and distributing them amongst the groups. These preservice teachers used Slowmations to identify their students' alternative conceptions and were able to offer feedback to their students about their learning in a variety of forms. Seeing their students' alternative conceptions led these preservice teachers to think carefully about the ways in which they had presented science concepts and to consider revising their teaching approach for future classes.

The preservice teachers in this study realised that which Scott et al. (1994) noted, that when teaching from a constructivist perspective, even when the concept has been well taught with opportunities for practical activities and discussion, students may still formulate conceptions that are not in accord with that which the teacher intended or expected. Slowmation gave these preservice teachers the opportunity to see how their students had interpreted what they taught in ways that otherwise might not have been recognized. They were also able to consider how, when and why they would use Slowmation as a Teaching Procedure in the future and in other classes; aside from the one that they had used during their practicum.

The many aspects of producing a Slowmation provided some great opportunities for these preservice teachers to vary their modes of assessment. They found that the storyboard, movie, script and presentation to the class could all be assessed as separate entities which meant that a large variety of skills could be assessed - essentially through one task. These preservice teachers also saw that their students were able to further their abilities in many other areas aside from 'just the science'. These areas included: computer skills; creative writing; group work; and, research.

Some of these preservice teachers found that they had to do a little convincing in order to persuade their supervising teacher to let them use Slowmation during their practicum. In some cases they identified that the supervisor had viewed Slowmation simply as a fun activity that could be used to fill in time - something which the teacher educators had recognized as important to avoid. The teacher educators involved in this study viewed this as a central issue within their pedagogy of teacher education (Loughran, 2006) and further reinforces Appleton's (2002) concern about preservice teachers seeing teaching through the lens of "activities that work".

The data from this preliminary study clearly demonstrates that these preservice teachers returned to their teacher education program with new insights into how to use Slowmation as a Teaching Procedure. They incorporated Slowmation into their teaching and came to see benefits for their students' learning as it assisted them in coming to better understand the ways in which their students developed their science knowledge.

\section{References}

Appleton, K. (2002). Science activities that work: Perceptions of primary school teachers. Research in Science Education, 32(3), 393 - 410. 
Baird, J. R., \& Mitchell, I. J. (Eds.). (1986). Improving the quality of teaching and learning: An Australian case study - The PEEL project. Melbourne: Monash University Printing Service.

Baird, J. R., \& Northfield, J. R. (Eds.). (1992). Learning from the PEEL experience. Melbourne: Monash University Printing Service.

Driver, R. (1994). Making sense of secondary science : research into children's ideas. London ; New York: Routledge.

Fensham, P. J., Gunstone, R. F., \& White, R. T. (1994). The Content of science: a constructivist approach to its teaching and learning. London ; Bristol, Pa.: Falmer Press.

Hoban, G. (2007). Using slowmation to engage preservice elementary teachers in understanding science content knowledge. Contemporary Issues in Technology and Teacher Education, $7(2), 1-9$.

Hoban, G., \& Ferry, B. (2006). Teaching science concepts in higher education classes with slow motion animation (slowmation). Paper presented at the E-Learn 2006 World Conference on E-Learning in Corporate, Government, Healthcare \& Higher Education, Honolulu, Hawaii.

Hoban, G., Loughran, J., Ferry, B., Berry, A., Erickson, G., \& Clarke, A. (2008). Generating Science Content Knowledge through Digital Animation in a Knowledge-building Community of Preservice Teachers. (2008-2010): Australian Research Council Grant.

Hoban, G., McDonald, D., \& Ferry, B. (2009). Improving Preservice Teachers' Science Knowledge by Creating, Reviewing and Publishing Slowmations to Teacher Tube. Paper presented at the Society for Information Technology \& Teacher Education International Conference 2009. from http://www.editlib.org/p/31126

Loughran, J. J. (2006). Developing a pedagogy of teacher education: Understanding teaching and learning about teaching. London: Routledge.

Mitchell, I. (2007). Teaching for Effective Learning: The complete book of PEEL teaching procedures. Clayton, Victoria: PEEL Publishing.

Mitchell, I., \& Mitchell, J. (1997). Stories of Reflecting Teaching: A Book of PEEL Cases. Mlebourne: Monash University Printing Service.

Nicaise, M., \& Crane (1999). Knowledge constructing through hypermedia authoring. Educational Technology, Research and Development, 47(1), 29-50.

Setiawan, Adib Rifqi. (2020a). Pembelajaran Tematik Berorientasi Literasi Saintifik. Jurnal Basicedu: Journal of Elementary Education, 04(01): 71-80. URL: https://jbasic.org/index.php/basicedu/article/view/298

Setiawan, Adib Rifqi. (2020b). Pendidikan Literasi Finansial Melalui Pembelajaran Fiqh Mu'āmalāt Berbasis Kitab Kuning. Nazhruna: Jurnal Pendidikan Islam, 03(01): 138-159. URL: http://ejournal.ikhac.ac.id/index.php/NAZHRUNA/article/view/522

Setiawan, Adib Rifqi; Mufassaroh, Arij Zulfi. (2019). Menyusun Soal Literasi Saintifik untuk Pembelajaran Biologi Topik Plantae dan Animalia. BIOSFER: Jurnal Biologi dan Pendidikan Biologi, 04(01): 33-40. URL: http://dx.doi.org/10.23969/biosfer.v4i1.1484

Setiawan, Adib Rifqi. (2017). Penerapan Pendekatan Saintifik untuk Melatihkan Literasi Saintifik dalam Domain Kompetensi pada Topik Gerak Lurus di Sekolah Menengah Pertama. Undergraduate Thesis. Bandung: Universitas Pendidikan Indonesia. URL: http://repository.upi.edu/29074/

Scott, P., Asoko, H., Driver, R., \& Emberton, J. (1994). Planning and Teaching a Chemistry Topic from a Constructivist Perspective. In P. J. Fensham, R. F. Gunstone \& R. T. White (Eds.), The Content of science: a constructivist approach to its teaching and learning (pp. 201-220). London ; Bristol, Pa.: Falmer Press. 